Syntax Fusion : Jurnal Nasional Indonesia

p-ISSN: -

e-ISSN : 2775-4440

Vol. 1, No. 7, Juli 2021

\title{
IMPLIKASI UTILITARIANISME PADA PENINDAKAN KEKERASAN TERHADAP REMAJA PEREMPUAN
}

\author{
Iqbal Maulana Akhsan
}

UIN Sunan Gunung Djati Bandung

Iqbalmaulana21.im@gmail.com

\begin{abstract}
Abstrak
Kasus kekerasan terhadap perempuan dari tahun ke tahun masih banyak saja kasus yang terjadi. Dari sekian banyak kasus yang terlapor masih saja ada kasus yang tidak dilaporkan kepada pihak berwajib. Tujuan dari tulisan ini ialah untuk mengetahui implikasi dari utilitarianisme pada penindakan kekerasan terhadap remaja perempuan, terutama dalam hubungan pacaran pada remaja. Kekerasan dalam pacaran setidaknya meliputi: kekerasan fisik, psikis, ekonomi, dan seksual. Utilitarianisme sebagai dasar pengambilan keputusan yang berdasarkan kepada kebahagiaan yang berdasarkan kuantitatif ini berakibat kepada tidak dilaporkannya kasus kekerasan terhadap remaja perempuan dalam pacaran. Berkurangnya kebahagiaan atau ketengangan yang didapatkan oleh orang-orang yang terkait dengan korban mengakibatkan tidak dilaporkannya kasus kekerasan remaja perempuan dalam pacaran. Kebahagiaan berupa ketenangan dalam hidup dan masalah yang dianggap sepele oleh orang yang terkait dengan korban mengakibatkan tidak dilaporkannya kasus kekerasan.
\end{abstract}

Kata Kunci: Kekerasan; Remaja Perempuan; Utilitarianisme

\section{Pendahuluan}

Kasus kekerasan yang dialami perempuan di Indonesia pada tahun 2020 berjumlah 299.911 (Komnas Perempuan, 2021). Kekerasan terhadap perempuan ini terjadi di ranah privat (keluarga) atau ranah publik. Dari 299.991 kasus kekerasan pada tahun 2020, terdapat 801 kasus kekerasan pada remaja perempuan. Kekerasan pada remaja perempuan ini diantaranya karena adanya hubungan antara korban dan pelaku, baik berupa hubungan keluarga, sahabat, percintaan, dsbnya.

Remaja yang seharusnya mengeluarkan segala apresiasi dan idenya untuk kebaikan masa depan mereka sendiri dan lingkungan sekitarnya, malah terjerumus ke dalam rusaknya masa depan mereka sendiri. Banyak dari para remaja perempuan terjerumus kepada hal yang akan berdampak negatif bagi diri mereka sendiri, diantaranya: lingkungan keluarga yang kurang baik dan efek traumatis dari kekerasan terhadapnya. 
Dari banyaknya kasus yang terlapor, kita tidak bisa menutup mata dari kebenaran bahwa masih ada kasus-kasus kekerasan yang tidak dilaporkan karena berbagai hal. hampir $80 \%$ dari korban kekerasan seksual tidak melaporkan kasusnya. Sebanyak 20\% mereka khawatir akan menerima stigma negatif dari masyarakat, $13 \%$ merasa bahwa kasusnya tidak akan dibantu atau diproses oleh pihak kepolisian, dan $8 \%$ menganggap perkosaan yang mereka alami tidak cukup penting untuk dilaporkan (Adinda, 2020). Selain itu, tidak dilaporkannya kasus kekerasan ini berbagai macam latar belakangnya, diantaranya karena akan melibatkan banyak pihak dalam prosesnya. Pelibatan kedua belah pihak dan mungkin besera keluarga besar ini, akan mengakibatkan ketidak nyamanan karena proses yang menguras banyak waktu, tenaga dan mungkin materil.

Pada kekerasan seksual pada remaja perempuan yang dijalankan dengan proses ancaman, pemaksann dsb-nya yang akan berdampak pada fisik, psikologis, maupun sosial korban. Dampak fisik dapat berupa luka pada bagian vital korban. Dampak psikologis bisa berupa trauma dan kesehatan mental yang terganggu yang dapat membahayakan nyawa korban. Dan dampak sosial berupa perlakuan tidak mengenakan dari masyarakata dengan mendapatkan stereotip negatif dari masyarakat yang mengakibatkan ketakutan dalam pergaulan dsbnya (Purbararas, 2018).

Dengan keterlibatan banyak pihak yang akan mengganggu ketenangan pihakpihak terkait. Hal ini akan mengakibatkan kebahagian atau ketenangan yang pada mulanya ada pada setiap individu akan berkurang, bahkan mungkin hilang karena proses yang berjalan. Terlebih pada kasus kehamilan perempuan di luar nikah yang kemudian dinikahkan oleh pihak keluarga yang dikenal dengan Marriged by Accident (MBA).

Selain dari itu, kekerasan yang dialami oleh remaja perempuan yang sedang menjalani suatu hubungan dengan lelaki tanpa ada ikatan nikah (pacaran) juga sering terjadi. Kekerasan ini dapat berupa kekerasan fisik, emosional, verbal, psikologis, dan lain-lain.

Jeremy Bentham menyatakan bahwa keputusan yang diambil meletakkan kebermanfaatan sebagai tujuan utama. Kebermanfaatan ini dimaknai sebagai bentuk kebahagian yang tidak mempermasalahkan dan mempertanyakan baik serta tidak adilnya suatu hukum, akan tetapi tergantung kepada pembahasan mengenai apakah hukum dapat memberikan kebahagian atau tidak kepada manusia. Lebih lanjut lagi, Bentham menyatakan bahwa, prinsip kebergunaan harus diterapkan secara angka atau kuantitatif, karena kualitas kesenangan selalu sama, satu satunya aspeknya yang bisa berbeda adalah kuantitasnya (Budiastuti, 2019).

Artikel ini akan membahas bagaimana implikasi dari utilitarinisme di masyarakat pada penindakan kekerasan terhadap remaja perempuan terutama pada kekerasan dalam pacaran.

\section{Metode Penelitian}

Metode penelitian yang digunakan pada artikel ini adalah studi kepustakaan berupa buku, artikel, dsb-nya. Data yang digunakan dalam penelitian ini berasal dari 
media sosial dan internet yang berkaitan dengan kekerasan pada remaja perempuan yang sedang menjalani proses pacaran.

\section{Hasil dan Pembahasan}

Pacaran yang dilakukan oleh remaja, terutama mereka yang berada di bangku sekolah menengah, setidaknya para remaja ini pernah berpacaran sebanyak lebih dari 4 kali (Purnama, 2016). Remaja-remaja yang berpacaran setidaknya memiliki alasan-alasan yang mendorong untuk berpacaran seperti untuk bersenang-senang, adanya ketertarikan satu sama lain, mencari status, memilih pasangan hidup dsb-nya. Selain itu, Susanto (1997) menjelaskan bahwa saling membantu dan membutuhkan serta saling memotivasi termasuk kepada hal yang mendorong untuk berpacaran.

Pacaran yang sebelumnya memiliki fungsi sebagai penyeleksian pasangan untuk masuk ke jenjang pernikahan dan diawasi dengan orang tua, mengalami pergeseran dari positif menjadi negative. Pergesaran pacaran pada masa awal yang positif dengan yang terjadi dewasa ini, salah satu penyebabnya ialah pengaruh adanya pergeseran kebudayaan masyarakat yang tidak bisa dilepaskan dari adanya peran globalisasi dan digitalisasi yang mempengaruhi kebudayaan masyarakat tersebut. Blum (dalam Notoatmojo, 2003) mengatakan faktor kebudayaan masyarakat yang menjadi sebuah lingkungan akan mempengaruhi individu dan kelompok masyarakat itu sendiri.

Bergesernya pacarana yang dulu diawasi oleh orang tua yang merupakan hal positif berubah menjadi hal yang negatif ini mengakibatkan berbagai hal yang tidak diinginkan terjadi. Menurut data Riskesdas (dalam Nugroho, 2015) kelompok remaja kelompok usia 15-17 tahun sebanyak 463 responden telah melakukan hubungan seksual dengan pasangannya di luar pernikahan. Hubungan seksual yang dilakukan oleh para remaja tadi memiliki berbagai latar belakang dan salah satunya ialah latar belakang kekerasan berupa paksaan, ancaman, dsbnya. Dan apabila dilakukan secara paksaan dan ancaman maka ini termasuk kepada kekerasan. Selain dari kekerasan seksual, masih ada berbagai jenis kekerasan pada pacaran berikut ini.

1. Kekerasan dalam Pacaran Pada Remaja Perempuan

Kekerasan dalam pacaran tidak memandang masalah di aitu laki-laki ataupun perempuan. Namun, sudah tidak asing lagi bahwa laki-laki lah yang memegang kuasa dalam suatu hubungan dan korbannya adalah perempuan. Hal ini disampaikan oleh Sunarto (2004), dalam ranah domestik maupun public, kekuasaan yang dimiliki perempuan cenderung lebih kecil apabila dibandingkan dengan kekuasaan laki-laki. Hal tersebut menyebabkan perempuan lebih rentan menjadi korban kekerasan, begitupun dalam pacaran. Bentuk-bentuk kekerasan terhadap remaja perempuan, diantaranya; kekerasan fisik, kekerasan emosional atau psikis, kekerasan ekonomi, hingga kekerasan seksual (Ferlita, 2008).

Davis (2008) mendefinsikan kekerasan fisik sebagai perilaku kekerasan yang memiliki tujuan untuk mengendalikan atau menyakiti pasangan. Dampak dari kekeran fisik ini yaitu munculnya luka pada fisik korban. Namun, kekerasan fisik pun dapat diartikan sebagai bentuk kontak apapun yang tidak diinginkan pada tubuh seseorang 
kendati pun tidak meninggalkan bekas luka (Wulandaru dkk, 2019). Bentuk-bentuk kekerasan fisik yang sering dilakukan terhadap remaja perempuan diantarnya ialah pelemparan barang ke tubuh, menggigit, menjambak rambut, memukul, dan menampar seperti yang ditemukan di Kecamatan Tembalang Kota Semarang (Wulandaru dkk, 2019). Kekerasan fisik ini berawal dari kekerasan verbal. Sebab, biasanya kekerasan verbal biasanya menjadi penanda bahwa hubungan memiliki potensi untuk menjadi kekerasan fisik. Namun, beberapa remaja salah mengartikan bahwa kekerasan verbal merupakan bentuk tanda cinta terhadap pasangannya (Mardiah dkk, 2017).

Sedangkan kekerasan emosional atau psikis lebih dirasakan pada perasaan sakit hati, tertekan, marah, terkekang, minder, dan perasaan lain yang membuat tidak nyaman. Kekerasan psikis ini tidak mudah teridentifikasi karena tidak menimbulkan bekas luka sebagaimana kekerasan fisik. Wujud kongkrit kekerasan atau pelanggaran jenis ini adalah pengunaan kata-kata kasar, penyalahgunaan kepercayaan, mempermalukan orang di depan orang lain atau di depan umum, melontarkan ancaman dengan kata-kata dan sebagainya. Selain itu, bersikap posesif (rasa memiliki yang tinggi) pun termasuk kepada kekerasan psikis.

Selanjutnya bentuk kekerasan ekonomi yang bersangkutan dengan kepemilikan materil baik berupa uang ataupun barang, misalnya: mengambil barang atau uang pasangan tanpa izin terlebih dahulu atau bahkan mengambil dan tidak pernah dikembalikan. Asosiasi Perempuan Asli Ontairo (dalam Wulandaru dkk, 2019) juga menyebutkan bahwa mencegah pasangan mendapatkan atau mempertahankan pekerjaan, membuatnya meminta uang, memberinya uang saku, mengambil uangnya juga merupakan sebuah tindak kekerasan ekonomi.

Kekerasan seksual adalah setiap perilaku yang tidak diinginkan. Hal ini seperti dipaksa dicium oleh pacarnya, mulai meraba-raba tubuh, bahkan memaksa untuk melakukan hubungan seksual. Umumnya kekerasan seksual, terutama pemerkosaan dalam masa pacarana, diawali oleh tindakan kekerasan yang lain (Ayu dkk, 2012). Seperti tindakan kekerasan ekonomi yang memaksa untuk melakukan hubungan intim dengan ancaman tidak diberi materil untuk kebutuhan sehari-hari dsbnya.

2. Utilitarianisme

Teori utilitarianisme di gagas oleh Jeremy Bentham menganggap bahwa suatu pengambilan suatu keputusan ialah untuk memberi kebermanfaatan atau kebagian yang sebesar-besarnya bagi masyarakat. Menurutnya, suatu perbuatan dapat dikatakan baik apabila membawa manfaat bukan untuk satu atau dua orang saja melainkan masyarakat secara keseluruhan.

Pengambilan keputusan in tidaklah perlu untuk melihat baik dan buruknya, adil dan tidak adilnya suatu keputusan. Namun hal itu, sangat bergantung apakah keputusan tersebut mampu memberikan kebahagian kepada manusia atau tidak. Dan kebahagian yang dimaksud dalam utilitarianisme ini adalah kebahagian terbesar dilihat dari jumlah orang yang menerima kebahagian (Besar, 2016). Dari terlihat jelas bahwa definisi kebahagiaan menurut utilitarianisme bukan berdasarkan kepada kualitasnya namun berdasarkan kuantitas. 
Ironisnya, konsep utilitariaisme ini akan menilai suatu tindak pelanggaran yang tidak merugikan orang banyak, sebaiknya tidak dianggap sebagai tindakan criminal. Penetapan sebagai tindakan criminal hanya bisa diterima apabila tindakan tersebut dapat memberikan harapan atas tercegahnya kejahatan (berukurangnya kemanfaatan) yang lebih besar (Prasetyo \& Barkatullah, 2013).

Utilitarianisme Bentham ini tidak membedakan kebahagian atau kesenangan yang lebih tinggi dan lebih rendah. Selain ketidak jelasan proporsi kebahagian, teori ini tidak dilengkapi dengan definisi yang tedas mengenai kebahagian, alat ukurnya, dan bimbingan moral di dalamnya yang akan mengakibatkan bahwa teori utilitarianisme ini tidak selalu sesuai dengan perasaan umum tentang keadilan (Ali, 2012).

3. Implikasi Utilitarianisme Terhadap Kekerasan Remaja Perempuan

Individu pada hakikatnya telah memiliki kebahagian pada diri mereka sendiri sesuai dengan kadar kebahagainnya yang berbeda-beda. Individu cenderung untuk mempertahankan, bahkan mengharapkan dan mencari kebahagian yang lebih.

Kebahagian yang menjadi konsep utama dalam utilitarianisme, menimbulkan permasalahan apabila dikaitakan dengan kasus kekerasan remaja perempuan, terutama dalam hubungan pacarana.

Implikasi dari utilitarianisme yang berfokus pada kebahagian yang bersifat kuantitatif akan mengakibatkan adanya keengganan melapor kepada pihak terkait bagi korban kekerasan terutama kekerasan dalam pacarana.

Tidak melapornya korban kekerasan pacarana pada remaja perempuan baik berupa kekerasan fisik, emosional atau psikis, seksual dan ekonomi karena akan mengakibatkan berkurang atau bahkan hilangnya kebahagiaan yang telah ada pada setiap individu. Hilangnya kebahagian perorangan yang ada di dekat korban akan berkurang dengan adanya pelaporan tersebut.

Selain itu pula, dianggap remehnya kekerasan terhadap remaja perempuan dalam pacarana ini yang juga akan menghilangkan rasa kebahagiaan berupa ketenangan yang menyebabkan kekerasan dalam pacarana yang dialami oleh remaja perempuan sebagian besarnya tidak dilaporkan.

\section{Kesimpulan}

Kekerasan dalam pacarana sering kali dialami oleh remaja perempuan. Hal ini karena dominasi laki-laki dalam hal yanga ada diruang public dsbnya. Bentuk kekerasan dalam pacarana yang dialami oleh remaja perempuan meliputi: kekerasan fisik, kekerasan psikis, kekerasan ekonomi, dan kekerasan seksual.

Kurangnya pelaporan tindak kekerasan yang disebutkan di atas karena adanya paham utilitarianisme di kehidupan bermasyarakat. Utilitarianisme yang berlandaskan kepada kebahagain yang paliing banyak atau berlandaskan berdasarkan kuantitatif.

Hal ini berakibat kepada korban tidak melaporkan tindak kekerasan yang akan mengurangi rasa kebahagian berupa ketenangan orang-orang terdekatnya akan permasalah ini. 


\section{Bibliografi}

Adinda, P. (2020, Februari 20). Asumsi.com. Retrieved from

Ali, A. (2012). Menguak Teori Hukum dan Teori Keadilan, Termasuk Interpretasi Undang-Undang. Bogor: Ghalia Indonesia.

Ayu, S. M., Hamiki, M., \& Hayati, E. N. (2012). Kekerasan Dalam Pacaran dan Kecemasan Remaja Putri di Kabupaten Purwerejo. Kes Mas 6 (1), 61-74.

Besar, B. (2016, Juni 30). Rubrik of Faculty Members. Retrieved from Binus University, Faculty of Humanity: https://business-

Budiastuti, S. R. (2019). Implikasi Konsep Utilitarianisme dalam Penegakan Hukum Tindak Pidana Narkotika: Kajian Putusan Pengadilan Negeri Yogyakarta Nomor 389/Pid.Sus/2015/PN.Yyk. Wacana Hukum 25 (2), 16-29.

Davis, A. (2008, September ). Interpersonal and Physical Dating Violence among Teens. Retrieved from Evident Change:

Ferlita, G. (2008). Sikap Terhadap Kekerasan Dalam Berpacaran (Penelitian Pada Mahasiswi Reguler Universitas Esa Unggul Yang Memiliki Pacar). Jurnal Psikologi 6 (1), 10-24.

Mardiah, A., Satriana, D. P., \& Syahriati, E. (2017). Peranan Dukungan Sosial Dalam Mencegah Kekerasan Dalam Pacaran: Studi Korelasi Pada Remaja di Jakarta. Jurnal Psikologi Ulayat 4 (1), 29-42.

Notoatmodjo, S. (2003). Pendidikan dan Perilaku Kesehatan. Jakarta: Rinekacipta. Nugroho, A. D. (2015). Faktor Yang Mendorong Perilaku Berpacaran Remaja (Studi Deskriptif di SMA Kota Surabaya). Skripsi. Surabaya: Unair.

Perempuan, K. (2020). Catatan Akhir Tahun. Jakarta: Komnas Perempuan.

Prasetyo, T., \& Barkatullah, A. H. (2013). Filsafat, Teori, dan Ilmu Hukum: Pemikiran Menuju Masyarakat yang Berkeadilan dan Bermartabat. Jakarta: Rajawali Press.

Purbararas, E. D. (2018). Problema Traumatik: Kekerasan Seksual Pada Remaja 2 (1). Ijtimaiya, 63-89.

Purnama, F. (2016). Kekerasan Dalam Pacara Pada Remaja. Harkat: Media Komunikasi Islam Tentang Gender dan Anak 12 (2), 161-170.

Sunarto, K. (2004). Pengantar Sosiologi . Depok: Lembaga Penerbit Fakultas Ekonomi Universitas Indonesia.

Susanto, M. W. (1997). Alasan-alasan berpacaran pada remaja dan faktor-faktor yang berkaitan dengan pola alasan berpacaran khususnya pada alasan konformitas (Studi eksploratik pada remaja SMU di Jakarta Selatan) Skripsi. Depok: UI.

Wulandaru, H. P., Bhima, S. K., Dhanardhono, T., \& Rohmah, I. N. (2019). Prevelensi dan Bentuk Kekerasan Dalam Pacaran Pada Siswa SMA, SMK, dan MA di Kecamatan Tembalang Kota Semarang. Jurnal Kedokteran Diponegoro 8 (4), $1135-1148$. 